\title{
Clinical features of aseptic meningitis with varicella zoster virus infection diagnosed by next-generation sequencing: case reports
}

Lanlan Chen ${ }^{1 \dagger}$, Yao Xu ${ }^{1 \dagger}$, Chunfeng Liư ${ }^{2}$, Hong Huang ${ }^{3}$, Xingxing Zhong ${ }^{1}$, Cancan Ma ${ }^{1}$, Haina Zhao and Yingzhu Chen ${ }^{1 *}$ (D)

\begin{abstract}
Background: The aseptic meningitis caused by varicella zoster virus (VZV) reactivation was less described in the literature, most of which were detected by means of polymerase chain reaction. The authors presented 4 adult immunocompetent patients with acute aseptic meningitis with VZV infection diagnosed by next-generation sequencing (NGS).

Case presentation: Four patients were admitted to the hospital with headache and fever between March 2018 and August 2019. The median ages were 37 years (range $22-52$ years). The median symptoms onset to clinic time was 3.5 days (range 3-6 days). Two patients had signs of meningeal irritation. Rash occurred after the meningitis symptoms in 1 patient (time from meningitis symptoms to rash, 2 days). No other sign or symptom was reported. The brain Magnetic resonance imaging and electroencephalography were normal in all patients. Cerebrospinal fluid (CSF) samples were obtained at a median of 4 days (range 3-7 days) from the meningitis symptoms onset. Opening pressure of lumbar puncture after admission were high in these cases (median $256 \mathrm{~mm} \mathrm{H} 2 \mathrm{O}$; range 165-400 $\mathrm{mm}$ $\mathrm{H}_{2} \mathrm{O}$ ). White blood cell counts and protein levels were significantly elevated in CSF samples (median $317 \times 10 \wedge 6 / \mathrm{L}$, range 147-478 $\times 10 \wedge 6 / \mathrm{L}$; median $1.41 \mathrm{~g} / \mathrm{L}$, range $0.57-1.79 \mathrm{~g} / \mathrm{L}$ ). The cytology of CSF demonstrated a lymphocytic pleocytosis, and most multinuclear cells. The culture of CSF was negative for all 4 cases, while T-cell spot test was positive for 2 cases, who were administrated with anti-tuberculosis treatment for suspicious tuberculous meningitis. NGS of CSF (the Vision Medical Research Institute) detected specific sequences of VZV in the 4 cases within $72 \mathrm{~h}$ after admission. The inappropriate treatment were stopped while acyclovir were continued intravenously for 10-14 days. All patients recovered completely.
\end{abstract}

Conclusions: VZV is an infectious agent that causes aseptic meningitis in immunocompetent adults and could not be accompanied by skin manifestations. The NGS of CSF is a rapid detection for the identification and differentiation of meningitis in patients, which is of great importance for providing the rapid and accurate diagnosis and the targeted antimicrobial therapy for central nervous system infection.

Keywords: Next-generation sequencing, Varicella zoster virus, Cerebrospinal fluid, Aseptic meningitis, Case report

\footnotetext{
* Correspondence: yzchendr@163.com

${ }^{\dagger}$ Lan Lan Chen and Yao Xu contributed equally to this work.

'Department of Neurology, Northern Jiangsu People's Hospital, Medical

College of Yangzhou University, Yangzhou 225001, China

Full list of author information is available at the end of the article
}

(c) The Author(s). 2020 Open Access This article is licensed under a Creative Commons Attribution 4.0 International License, which permits use, sharing, adaptation, distribution and reproduction in any medium or format, as long as you give appropriate credit to the original author(s) and the source, provide a link to the Creative Commons licence, and indicate if changes were made. The images or other third party material in this article are included in the article's Creative Commons licence, unless indicated otherwise in a credit line to the material. If material is not included in the article's Creative Commons licence and your intended use is not permitted by statutory regulation or exceeds the permitted use, you will need to obtain permission directly from the copyright holder. To view a copy of this licence, visit http://creativecommons.org/licenses/by/4.0/ The Creative Commons Public Domain Dedication waiver (http://creativecommons.org/publicdomain/zero/1.0/) applies to the data made available in this article, unless otherwise stated in a credit line to the data. 


\section{Background}

Aseptic meningitis is an inflammation of the meninges associated with acute onset of headache, fever and neck stiffness, with pleocytosis of the cerebrospinal fluid, and no growth on routine bacterial culture [1]. The leading recognizable causes of aseptic meningitis include nonpolio human enteroviruses, mumps virus, lymphocytic choriomeningitis virus and herpesviruses [2]. Varicella zoster virus (VZV) reactivation is recognized as one of the most common neurological infectious diseases and VZV the second most frequent virus causing encephalitis [3]. VZV meningitis were less described in the literature, most of which involved adolescent or elderly patients and meanwhile the viruses were detected by means of polymerase chain reaction (PCR) [4].

We here described cases of 4 immunocompetent adults with aseptic meningitis due to VZV reactivation diagnosed by next-generation sequencing (NGS).

\section{Case presentation}

\section{Case no. 1}

On March 2018, a 52-year-old man was admitted to Northern Jiangsu People's Hospital because of headache for 4 days and fever $\left(37.6{ }^{\circ} \mathrm{C}\right)$ for 2 days. He had no other symptoms. The constant and progressive headache did not relieved after the routine treatment such as oral nonsteroidal analgesics. He had a history of chicken pox when he was 7 years old. He had symptomatic epilepsy since 8 years ago after a brain trauma, which occurred every 6 to 12 months. He had no sign of meningeal irritation, and vital signs were normal. No rash was seen at any stage (Table 1 ).

The white blood cell count was $11.23 \times 10^{\wedge} 9 / \mathrm{L}$ with $79 \%$ neutrophils. The serum electrolytes, hemoglobin, erythrocyte sedimentation rate, procalcitonin, and C-reactive protein were normal. The T-cell spot test was positive. The cerebrospinal fluid (CSF) contained $147 \times 10^{\wedge} 6 / \mathrm{L}$ white blood cells (WBCs) (reference range, $<8 \times 10^{\wedge} 6 / \mathrm{L}$ ); CSF protein was $1.72 \mathrm{~g} / \mathrm{L}$ (reference range, 0.2-0.4 g/L) (Table 2). Brain Magnetic resonance imaging (MRI) revealed pre-existing brain trauma lesions. The patient was started on intravenous acyclovir for possible herpes simplex virus infection, ceftriaxone for possible bacterial disease, as well as rifampin, isoniazid, pyrazinamide, and ethambutol for the possible tuberculosis infection. His CSF sample was immediately sent for pathogen detection by NGS at Vision Medical Research Institute, and it was sequenced on Illumina NextSeq500 platform using a 75-cycle single-end (see Additional file 1 for detailed detection process) [5]. The identified number of unique reads mapped on the VZV genome sequence was 17, 137, with genome coverage of $99.73 \%$, and read depth of 17.9 X (Table 3, Fig. 1). After filtering out low-complexity and shorter reads, the NGS analyses of other viruses, bacterial, mycoplasma, and tubercle bacillus were negative (Additional file 2).

After the diagnosis with VZV meningitis within $48 \mathrm{~h}$ after admission, the antibiotic and anti-tuberculosis treatment were stopped immediately. The acyclovir (10 $\mathrm{mg} / \mathrm{kg}$ t.i.d) were continued intravenously for 10 days. The patient's condition improved quickly. A repeat lumbar puncture on the ninth day after admission revealed improved WBCs $\left(39 \times 10^{\wedge} 6 / \mathrm{L}\right)$ and protein $(0.88 \mathrm{~g} / \mathrm{L})$ (Table 2). Thus he was discharged, and a month later on follow-up in the outpatient clinic, he had recovered completely.

\section{Case no. 2}

On November 2018, a 22-year-old man was admitted to Northern Jiangsu People's Hospital because of fever $\left(37.7^{\circ} \mathrm{C}\right)$, severe headache, and nausea for 3 days. One day before admission, he noticed vescicles in a very limited region of the left dorsal skin. No other sign or symptom was reported (Table 1). He was diagnosed of varicella when he was 4 years old. Upon admission, his vital signs were unremarkable, and the skin lesions located in a small part of the area supplied with level of 10 thoracic were considered consistent with a diagnosis with herpes zoster. Neurological examination was significant for neck stiffness and positive for Kernig signs.

The white blood cell count was $12.18 \times 10^{\wedge} 9 / \mathrm{L}$, while $81 \%$ neutrophils. The inflammatory biomarkers, same with those tested in case 1 , were within normal ranges. The opening pressure of lumbar puncture was $235 \mathrm{~mm}$ $\mathrm{H}_{2} \mathrm{O}$ (reference range, 90-180 $\mathrm{mm} \mathrm{H}_{2} \mathrm{O}$ ). The cytology of CSF demonstrated WBCs with $200 \times 10^{\wedge} 6 / \mathrm{L}$, and an increased protein concentration $(0.57 \mathrm{~g} / \mathrm{L})$ (Table 2$)$. The CSF was positive for VZV by NGS (Vision Medical Research Institute), with unique reads of sequences of 13 , 190 , the genome coverage of $98.83 \%$, and read depth of 11.87 X (Table 3, Fig. 1, Additional file 3).

Table 1 Demographic characteristics and clinical findings for cases

\begin{tabular}{|c|c|c|c|c|c|c|c|c|c|c|c|c|}
\hline $\begin{array}{l}\text { Case } \\
\text { No. }\end{array}$ & Gender & $\begin{array}{l}\text { Age } \\
(y)\end{array}$ & $\begin{array}{l}\text { Duration of symptome } \\
\text { before admittion (d) }\end{array}$ & $\begin{array}{l}\text { Duration of } \\
\text { hospitalization (d) }\end{array}$ & Headache & Fever & $\begin{array}{l}\text { Cutaneous } \\
\text { zoster }\end{array}$ & $\begin{array}{l}\text { Neck } \\
\text { stiffness }\end{array}$ & $\begin{array}{l}\text { Kernig } \\
\text { signs }\end{array}$ & EEG & MRI & $\begin{array}{l}\text { History of } \\
\text { chicken pox }\end{array}$ \\
\hline 1 & male & 52 & 4 & 10 & + & + & - & - & - & - & - & + \\
\hline 2 & male & 22 & 3 & 10 & + & + & + & + & + & - & - & + \\
\hline 3 & male & 45 & 6 & 14 & + & + & - & - & - & - & - & uncertain \\
\hline 4 & male & 29 & 3 & 10 & + & + & - & + & - & - & - & + \\
\hline
\end{tabular}


Table 2 Routine laboratory evalutions of CSF of the four cases

\begin{tabular}{|c|c|c|c|c|c|c|c|c|c|}
\hline $\begin{array}{l}\text { Case } \\
\text { No. }\end{array}$ & $\begin{array}{l}\text { Days from symptom onset } \\
\text { to CSF collection (d) }\end{array}$ & $\begin{array}{l}\text { Days from CSF } \\
\text { collection to diagnosis } \\
\text { (d) }\end{array}$ & $\begin{array}{l}\text { Total time to } \\
\text { diagnosis (d) }\end{array}$ & $\begin{array}{l}\text { Pressure } \\
\left(\mathrm{mm} \mathrm{H}_{2} \mathrm{O}\right)\end{array}$ & $\begin{array}{l}\text { WBC } \\
\left(\times 10^{6} /\right. \\
L)\end{array}$ & $\begin{array}{l}\text { Multinuclear } \\
\text { (\%) }\end{array}$ & $\begin{array}{l}\text { Protein } \\
(\mathrm{g} / \mathrm{L})\end{array}$ & $\begin{array}{l}\text { Glucose } \\
(\mathrm{mmol} / \mathrm{L})\end{array}$ & $\begin{array}{l}\text { Serum } \\
\text { glucose } \\
\text { (mmol/L) }\end{array}$ \\
\hline 1 & 4 & 2 & 2 & 165 & 147 & 1.4 & 1.72 & 3.82 & 6.80 \\
\hline 1 & 13 & I & I & 120 & 39 & 1.0 & 0.88 & 4.97 & 6.95 \\
\hline 2 & 3 & 2 & 2 & 235 & 200 & 1.0 & 0.57 & 3.88 & 4.74 \\
\hline 2 & 11 & I & I & 70 & 130 & 0.8 & 0.40 & 4.97 & 5.93 \\
\hline 3 & 7 & 2 & 3 & 400 & 478 & 0.2 & 1.79 & 7.03 & 8.37 \\
\hline 3 & 16 & I & I & 240 & 91 & 0.4 & 0.65 & 4.06 & 5.79 \\
\hline 4 & 4 & 2 & 3 & 275 & 434 & 0.7 & 1.10 & 3.72 & 4.77 \\
\hline 4 & 12 & I & / & 175 & 175 & 0.9 & 0.37 & 3.42 & 4.64 \\
\hline
\end{tabular}

Note: Total time to diagnosis = days to CSF collection+ days from CSF collection to NGS result

The patient was treated with acyclovir and ceftriaxone after admission. After VZV was detected, ceftriaxone was stopped and acyclovir $(10 \mathrm{mg} / \mathrm{kg}$ t.i.d) was continued intravenously for 10 days. The therapy was highly effective and the patient's clinical condition rapidly improved. The CSF on the eighth day after the admission revealed WBCs with $130 \times 10^{\wedge} 6 / \mathrm{L}$, and protein $(0.40 \mathrm{~g} / \mathrm{L})$ (Table 2 ). The patient was discharged after 10-day treatment. An examination carried out about 4 weeks later did not find any sign or symptom of disease.

\section{Case no. 3}

On August 2019, a 45-year-old man with headache for 6 days was admitted to our hospital. He felt fatigued and headache, never measured his temperature. No other sign or symptom was reported. No positive sign of neurological examination was detected (Table 1). A low fever of less than $38.0^{\circ} \mathrm{C}\left(37.8^{\circ} \mathrm{C}\right.$ on the first day, $37.6^{\circ} \mathrm{C}$ on the second day, $37.7^{\circ} \mathrm{C}$ on the third day) was found every afternoon since the second day after admission. The white blood cell count was $13.45 \times 10^{\wedge} 9 / \mathrm{L}$, while $79 \%$ neutrophils. The inflammatory biomarkers, same with those tested in case 1 and case 2, were within normal ranges. The lumbar puncture on the second day after admission revealed significantly increased opening pressure of CSF $\left(400 \mathrm{~mm} \mathrm{H}_{2} \mathrm{O}\right)$. The CSF contained $478 \times 10^{\wedge} 6 / \mathrm{L}$ WBCs; CSF protein was $1.79 \mathrm{~g} / \mathrm{L}$ (Table 2). The T-cell spot test was positive. The patient was treated with intravenous mannitol, acyclovir, ceftriaxone, as well as rifampin, isoniazid, pyrazinamide, and ethambutol for the possible tuberculosis infection. His CSF sample was immediately tested by NGS at Vision Medical Research Institute. The sequencing detection identified 1330 sequence reads uniquely corresponding to the VZV, with the genome coverage of $34.77 \%$ (Table 3, Fig. 1, Additional file 4).

After etiological diagnosis was identified, antibiotic and anti-tuberculosis treatment were stopped immediately. The intravenously acyclovir was continued for total 14 days, while mannitol was for the total 11 days with a gradually decreased dose. The disease made rapid progress. A repeat lumbar puncture on the eleventh day after admission revealed improved WBCs $\left(91 \times 10^{\wedge} 6 / \mathrm{L}\right)$ and protein $(0.65 \mathrm{~g} / \mathrm{L})$ (Table 2). Thus he was discharged from hospital. A month later on follow-up in the outpatient clinic, he had recovered completely.

\section{Case no. 4}

On August 2019, a 29-year-old man with a fever $\left(38.0^{\circ} \mathrm{C}\right)$ and a progressive headache was admitted to Northern Jiangsu People's Hospital. His disease began with headache and nausea 3 days earlier. No other symptom was developed. Neurological examination was moderate for neck stiffness and negative for Kernig signs (Table 1). The white blood cell count was $13.73 \times 10^{\wedge} 9 /$ $\mathrm{L}$, while $82 \%$ neutrophils. The results of routine inflammatory biomarkers, same with those tested in other cases, were normal. The second day after the admission,

Table 3 Number, percentage, genome coverage, and read depth of unique reads for the sequences of varicella zoster virus in the CSF samples

\begin{tabular}{llllll}
\hline Case No. & Pathogen & Unique reads & Percentage, \% & Genome Coverage, \% & Read Depth $(X)$ \\
\hline 1 & varicella zoster virus & 17,137 & 100 & 99.73 & 17.90 \\
2 & varicella zoster virus & 13,190 & 100 & 98.83 & 11.87 \\
3 & varicella zoster virus & 1330 & 100 & 34.77 & 1.25 \\
4 & varicella zoster virus & 102 & 96.23 & 4.32 & 1.03
\end{tabular}

Note: In case 1, 2, and 3, only VZV has been detected by NGS. So, the percentage is $100 \%$ for each of them. In case 4 , there were 102 reads of VZV and 4 reads of Human parvovirus B19 detected by NGS (Additional file 5). So, the percentage is $96.23 \%(102 / 106)$ for case 4 

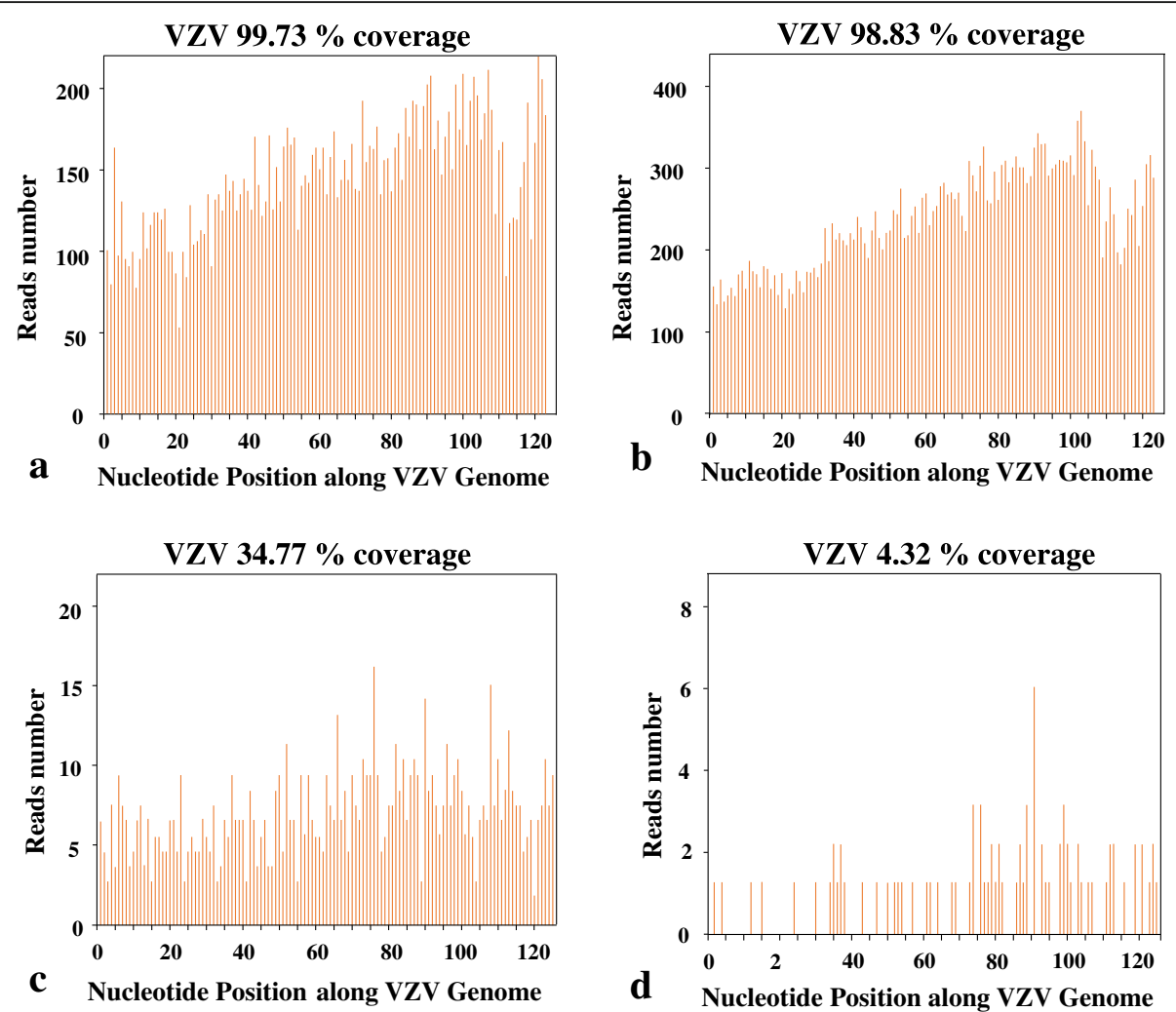

Fig. 1 Reads mapping to VZV genome, generated with NGS from CSF. a In case No. 1, the viral reads (17,137 reads) corresponded to varicella zoster virus, with a genome coverage of $99.73 \%$. b In case No. 2, the viral reads (13,190 reads) corresponded to varicella zoster virus, with a genome coverage of $99.83 \%$. $\mathbf{c}$ In case No. 3, the viral reads (1330 reads) corresponded to varicella zoster virus, with a genome coverage of $34.77 \%$. $\mathbf{d}$ In case No. 4, the viral reads (102 reads) corresponded to varicella zoster virus with a genome coverage of $4.32 \%$

the opening pressure of lumbar puncture showed $275 \mathrm{~mm}$ $\mathrm{H}_{2} \mathrm{O}$, and the CSF contained $434 \times 10^{\wedge} 6 / \mathrm{L}$ WBCs (Table 2). The patient was started on intravenous acyclovir of $10 \mathrm{mg} /$ $\mathrm{kg}$ t.i.d and mannitol of $250 \mathrm{ml}$ b.i.d. DNA of VZV was identified in the CSF using NGS (Vision Medical Research Institute). The sequencing detection identified 102 sequence reads uniquely corresponding to the VZV, with genome coverage of $4.32 \%$ (Table 3, Fig. 1, Additional file 5). The intravenous acyclovir were administered for 10 days, and the patient's condition improved quickly. A repeat lumbar puncture on the eighth day after the admission revealed normal pressure of $175 \mathrm{~mm} \mathrm{H}_{2} \mathrm{O}$, improved WBCs $\left(129 \times 10^{\wedge} 6 / \mathrm{L}\right)$, and normal protein $(0.37 \mathrm{~g} / \mathrm{L})$ (Table 2). Thus he was discharged from hospital. A month later on follow-up in the outpatient clinic, he had recovered completely.

The sequence-specific PCR identification of VZV was carried out to validate the NGS results for the 4 cases. The specific primers used for the gene amplification were VZV-F2 (GACAATATCATATACATGGAATGT G) and VZV-R2 (GCGGTAGTAACAGAGAATTT CTT). The results showed that the read from Sanger sequencing was consistent with VZV genome (see Additional file 1 for PCR results and Additional file 6 for original images) (Fig. 2).

\section{Discussion and conclusions}

VZV, belonging to the group of alpha-herpes viruses, causes varicella (chickenpox) and herpes zoster. Varicella usually results in mild to moderate illness in mainly childhood or immunocompetent patients with disseminated vesicular rash. After primary infection, VZV remains latent in sensory cranial nerve ganglia or dorsal root ganglia, when reactivated, replicates along the course of the nerve and appears as a localized vesicular skin rash. Viral reactivation can cause a wide range of neurologic disease, most frequently manifesting as herpes zoster and post-herpetic neuralgia [3]. Older age, immunocompromised state, bone marrow transplant recipients and possibly pregnancy are risk factors associated with higher severity of VZV. Aseptic meningitis is usually regarded as an uncommon complication of the cutaneous primary infection in patients with impaired cellular immunity. Recently, many studies reported that VZV was an important cause of aseptic infection in central nervous system (CNS), with the frequencies ranging from 5 to $27 \%[5,6]$.

The etiology of acute meningoencephalitis remains undiagnosed in approximately $60 \%$ of cases despite extensive clinical laboratory testing for infectious pathogens 

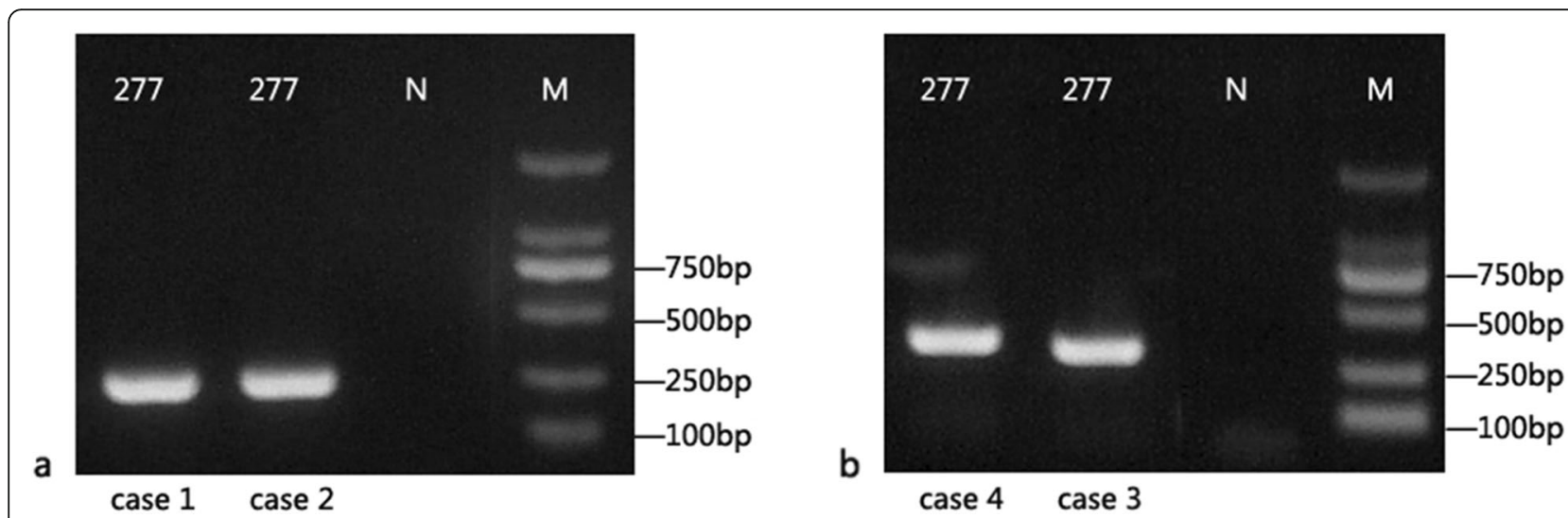

Fig. 2 Sanger sequencing detection of VZV from CSF specimen. M: DNA markers of DL2000 or Trans $2 \mathrm{~K}$ Plus. N: negative control. The number 277 bp represent the sample code. Original images were in Additional file 6

[7]. Till now, many diagnostic assays are based on polymerase chain reaction (PCR), which relies on sequencespecific primers. NGS has been applied as a diagnostic method to detect the pathogens for CNS infectious diseases in recent years. Many successful applications of NGS to the diagnosis with CNS infections have been reported $[8,9]$. The case series included 4 male adult patients who were diagnosis with VZV meningitis by NGS. Interestingly, all 4 patients presenting in this study were less than 50 years of age, although VZV reactivation were reported more commonly occurred in older adults [10]. This finding was similar to that in another study in which 5 of the 8 patients with VZV meningitis were presented before the fifth decade of life. None of them had traditional risk factors for VZV infection. The only one who had epilepsy history took antiepileptic drugs, rather than immunosuppressant drugs, which indicated that reactivation of VZV may be a more frequent cause of aseptic meningitis than previously anticipated in immunocompetent individuals. Koskiniemi et al. reported that 27 and $65 \%$ of patients with encephalitis and meningitis, respectively, had no skin manifestations, suggesting VZV could reactivate independently of vesicular eruptions, and spread directly to the leptomeninges [11]. In the present study, 3 patients (75\%) had no cutaneous zosteriform lesions, which was consistence with the previous study $[11,12]$.

Lumbar puncture revealed increased opening pressure of CSF (235-400 $\left.\mathrm{mm} \mathrm{H}_{2} \mathrm{O}\right)$ in three patients, and it was also on the high side $\left(165 \mathrm{~mm} \mathrm{H}_{2} \mathrm{O}\right)$ for the other one. All cases showed elevation in CSF WBC, ranging from 147 to $478 \times 10^{6} / \mathrm{L}$, and the CSF cytology indicated lymphocytic inflammation. It was regarded that mild elevation in CSF protein levels would been observed in aseptic meningitis. However, the relatively high CSF protein levels were reported seen in patients with VZV infection which were significantly higher than those seen in patients with enteroviral infection [12, 13]. Protein levels (median $1.41 \mathrm{~g} / \mathrm{L}$ ) in this study were higher than previously reported. All patients received acyclovir intravenously for 1-2 weeks resulting in full recovery, suggesting that VZV meningitis tends to be mild symptom, good response to treatment and benign prognosis.

The difficulty in meningitis diagnosis is to distinguish whether it's a viral or bacterial etiology, because this is crucial for treatment decisions. The treatment threshold is usually set low in clinical work, so that antibiotics, even anti-tuberculosis treatment, are often prescribed in cases of doubt, as were patients in this study. The patient of case No. 2 had vesicular rash before admission which made the diagnosis with aseptic meningitis relatively easy. However, the other 3 patients never showed cutaneous zosteriform lesions. Additionally, the T-cell spot test was positive for the second and fourth cases, meanwhile the protein levels in CSF elevated significantly for both these 2 patients, which implied possible tuberculosis infection, therefore anti-tuberculosis treatment as well as antibiotics were administrated. However, all the cases in our study were pathogen diagnosis within $72 \mathrm{~h}$ after admission. Once the sequences of VZV were detected by NGS, inappropriate treatment were stopped.

NGS is a rapid and accurate approach for the molecular diagnosis with diseases compared to traditional clinical testing. It could dramatically reduce the diagnostic period to less than 3 days [14]. Pathogen-specific PCR is widely used to detect common viruses like herpes simplex virus, VZV and enterovirus because of its high sensitivity and specificity. The turn-around time, which is the time taken from CSF collection to receipt result report, is often 2 days for PCR, and is comparable to that of the NGS test. Most centers around the world would consider NGS only for samples that have been tested negative by pathogen-specific PCR. However, our center opted for direct NGS instead of PCR in this study, for 3 
of the cases were difficult to distinguish between viral and bacterial etiology from CSF characteristic or clinical feature. The main limitation of PCR is the level to which assays can be multiplexed, which constrains the number of targets that can be assessed per reaction. For cases of common virus infection, the diagnosis will be quickly confirmed by PCR; for cases of other microorganism infection which are out of the PCR test range, the diagnosis time would be extended. In contrast, NGS is a highthroughput approach that can interrogate all genetic material in a biologic sample simultaneously [15]. It enable sequencing the total DNA or ribonucleic acid (RNA) from a human sample and identify all possible microorganism present in the specimen. Besides, NGS is an untarged assay as it can amplify and sequence the entire DNA content of a sample without using any primers or probes. The NGS results were further validated by Sanger sequencing in our cases, which was consistent with our expectation, and indicated the reliability of the results and the great practical guiding value of NGS.

VZV reactivation leading to aseptic meningitis in immunocompetent adults with or without cutaneous zoster is more common that previous regarded. Relatively high CSF protein levels could be observed in VZV meningitis. This study highlighted the feasibility of using NGS of CSF as a diagnostic tool for CNS infection. Unbiased NGS could facilitate identification of all the potential pathogens in a single assay theoretically, which is of great importance for providing the rapid and accurate diagnosis and the targeted antimicrobial therapy for CNS infection.

\section{Supplementary information}

Supplementary information accompanies this paper at https://doi.org/10. 1186/s12879-020-05155-8.

Additional file 1. Details of NGS detection process and the results of Sanger sequencing

Additional file 2. Microbe reads of bacterium, fungi, parasite and virus detected in Case No. 1

Additional file 3. Microbe reads of bacterium, fungi, parasite and virus detected in Case No. 2

Additional file 4. Microbe reads of bacterium, fungi, parasite and virus detected in Case No. 3

Additional file 5. Microbe reads of bacterium, fungi, parasite and virus detected in Case No. 4

Additional file 6. Original images for results of Sanger sequencing detection of VZV from CSF specimen

\section{Abbreviations}

CNS: Central nervous system; CSF: Cerebrospinal fluid; DNA: Deoxyribonucleic acid; EEG: Electroencephalography; MRI: Magnetic resonance imaging; NGS: Next-generation sequencing; PCR: Polymerase chain reaction; RNA: Ribonucleic acid; VZV: Varicella zoster virus; WBC: White blood cells

Acknowledgements

Not applicable.

\section{Authors' contributions}

$Y C$ is the principal investigator who drafted the original manuscript. LC participated in laboratory analysis of CSF and drafted parts of the origina manuscript. $Y X$ was involved in case and sample collection as well as analysis or interpretation of data. C L revised the manuscript. $\mathrm{H} \mathrm{H}$ performed the NGS and Sanger sequencing test. X Z was involved in case and sample collection and analysis of the data. C M was involved in case and sample collection and analysis of the data. $\mathrm{HZ}$ analyzed and interpreted the data. All authors have read and approved the manuscript.

\section{Funding}

This work was supported by the 333 Project of Jiangsu Province (BRA2015187), and Six kinds of Talent Summit Project funded by Jiangsu Province (WSW-246), for the publication of this article.

\section{Availability of data and materials}

All data generated or analysed during this study are included in this published article. The CSF was detected by mNGS (illumine Nextseq 550, Vision Medical Research Institute). The VZV DNA sequence assembled using the NGS data was submitted to GenBank (accession no. KY062165). Other microbe reads including that of bacterium, fungi, parasite and virus were listed in Additional files 2-5.

\section{Ethics approval and consent to participate}

All procedures performed in this study involving human participants were in accordance with the ethical standards of Ethics Committee of Northern Jiangsu People's Hospital.

\section{Consent for publication}

Written informed consents were obtained from patients for publication of this case report. Copies of the written consent for publication from the patients are available for review by the Editor-in-Chief of this journal.

\section{Competing interests}

The authors declare that they have no competing interests.

\section{Author details}

'Department of Neurology, Northern Jiangsu People's Hospital, Medical College of Yangzhou University, Yangzhou 225001, China. ${ }^{2}$ Department of Neurology, the Second Affiliated Hospital of Soochow University, Suzhou 215004, China. ${ }^{3}$ Vision Medical Co., Ltd, Guangzhou 510670, China.

Received: 25 April 2020 Accepted: 12 June 2020

Published online: 22 June 2020

\section{References}

1. McGill F, Griffiths MJ, Bonnett LJ, et al. Incidence, aetiology, and sequelae of viral meningitis in UK adults: a multicentre prospective observational cohort study. Lancet Infect Dis. 2018;18(9):992-1003.

2. Wright WF, Pinto CN, Palisoc K, et al. Viral (aseptic) meningitis: a review. J Neurol Sci. 2019;398:176-83.

3. Granerod J, Ambrose HE, Davies NW, et al. Causes of encephalitis and differences in their clinical presentations in England: a multicentre, population-based prospective study. Lancet Infect Dis. 2010;10(12):835-44.

4. Grahn A, Bergström T, Runesson J, et al. Varicella-zoster virus (VZV) DNA in serum of patients with VZV central nervous system Q6 infections. J Inf Secur. 2016;73(3):254-60

5. Blauwkamp TA, Thair S, Rosen MJ, et al. Analytical and clinical validation of a microbial cell-free DNA sequencing test for infectious disease. Nat Microbiol. 2019;4(4):663-74.

6. Kupila L, Vuorinen $T$, Vainionpää $R$, et al. Etiology of aseptic meningitis and encephalitis in an adult population. Neurology. 2006;66(1):75-80.

7. Glaser CA, Honarmand S, Anderson LJ, et al. Beyond viruses: clinical profiles and etiologies associated with encephalitis. Clin Infect Dis. 2006;43(12): 1565-77.

8. Wilson MR, O'Donovan BD, Gelfand JM, et al. Chronic meningitis investigated via metagenomic next-generation sequencing. JAMA Neurol. 2018;75(8):947-55

9. Brown JR, Bharucha T, Breuer J. Encephalitis diagnosis using metagenomics: application of next generation sequencing for undiagnosed cases. J Inf Secur. 2018;76(3):225-40. 
10. Meyers JL, Candrilli SD, Rausch DA, et al. Costs of herpes zoster complications in older adults: a cohort study of US claims database. Vaccine. 2019;37(9):1235-44.

11. Koskiniemi M, Piiparinen $H$, Rantalaiho T, et al. Acute central nervous system complications in varicella zoster virus infections. J Clin Virol. 2002;25(3):293-301.

12. Choi R, Kim GM, Jo IJ, et al. Incidence and clinical features of herpes simplex viruses (1 and 2) and varicella-zoster virus infections in an adult Korean population with aseptic meningitis or encephalitis. J Med Virol. 2014;86(6): 957-62.

13. Ihekwaba UK, Kudesia G, McKendrick MW. Clinical features of viral meningitis in adults: significant differences in cerebrospinal fluid findings among herpes simplex virus, varicella zoster virus, and Enterovirus infections. Clin Infect Dis. 2008;47(6):783-9.

14. Guan H, Shen A, LV X, et al. Detection of virus in CSF from the cases with meningoencephalitis by next-generation sequencing. J Neuro-Oncol. 2016; 22(2):240-5.

15. Xiao $H$, Huang $K$, Li L, et al. Complete genome sequence analysis of human echovirus 30 isolated during a large outbreak in Guangdong Province of China, in 2012. Arch Virol. 2014;159(2):379-83.

\section{Publisher's Note}

Springer Nature remains neutral with regard to jurisdictional claims in published maps and institutional affiliations.

Ready to submit your research? Choose BMC and benefit from:

- fast, convenient online submission

- thorough peer review by experienced researchers in your field

- rapid publication on acceptance

- support for research data, including large and complex data types

- gold Open Access which fosters wider collaboration and increased citations

- maximum visibility for your research: over $100 \mathrm{M}$ website views per year

At $\mathrm{BMC}$, research is always in progress.

Learn more biomedcentral.com/submissions 